\title{
ANALISIS PERSEPSI KONSUMEN PENGGUNA LAYANAN STREAMING FILM DARING (ONLINE) PADA MASA PANDEMI COVID-19 MENGGUNAKAN METODE IMPORTANCE PERFORMANCE ANALYSIS (IPA)
}

\author{
Muhamad Zaini' ${ }^{1}$, Maukar ${ }^{2}$ \\ Program Studi Sistem Informasi Bisnis ${ }^{1}$, Teknik Informatika ${ }^{2}$, Magister \\ Manajemen Sistem Informasi, Fakultas Teknologi Industri ${ }^{2}$, Universitas \\ Gunadarma $^{1}$, Universitas Gunadarma ${ }^{2}$ \\ muhamadzaini542@gmail.com, maukar@staff.gunadarma.ac.id
}

\begin{abstract}
Abstrak: Bermula dari merebaknya virus Corona jenis baru (SARS-CoV-2), yang disebut Corona Virus Disease 2019 (COVID-19), di dataran negeri Tiongkok tepatnya di provinsi Wuhan pada akhir 2019, seluruh negara di dunia seolah dihantam krisis besar. Skema WFH merupakan bagian dari konsep telecommuting (bekerja jarak jauh), yang sebenarnya bukan hal baru dalam dunia kerja dan perencanaan kota, bahkan telah dikenal sejak tahun 1970-an sebagai salah satu upaya mengatasi kemacetan lalulintas dari perjalanan rumah-kantor pulang-pergi setiap hari. Kebijakan pemerintah untuk menerapkan work from home (wfh) selama pandemi covid-19 berlangsung, membuat banyak orang mengakses hiburan lain di internet. Salah satunya dengan mengakses layanan streaming. pada kuartal I di 2020, tercatat sebanyak 59 juta pemasangan untuk Viu. Marketing mix (7P) merupakan langkah yang paling baik untuk mempertimbangkan segala factor operasional, hal ini dikarenakan marketing mix melihat dari segi produk, (makanan dan minuman), pelayanan, harga dan lokasi. Seiring perkembangan jaman, marketing mix berkembang menjadi 7 faktor dimana 3 faktor tambahannya itu berupa people, physical evidence serta process. Important Performance Analysis merupakan suatu teknik yang digunakan untuk mengukur tingkat kepentingan dan tingkat kinerja atribut. Penilaian tingkat kinerja yang dapat mempengaruhi kepuasan konsumen akan diwakili oleh huruf X, sedangkan untuk penilaian tingkat kepentingan diwakili oleh huruf Y. Berdasarkan hasil penelitian yang telah dilakukan, diperoleh kesimpulan bahwa kualitas kinerja aplikasi Viu masih belum memenuhi kebutuhan dan keinginan pelanggan. Tidak terpenuhinya kebutuhan dan keinginan pelanggan ditunjukkan oleh beberapa atribut yang masuk kedalam kuadran I pada diagram kartesius, yaitu: pemilihan atau permintaan film dilayani dengan cepat, keterampilan memikat konsumen melalui promo daring koleksi lengkap dan menarik, memikat konsumen melalui rekomendasi berdasarakan film yang disukai oleh konsumen, pada situs maupun aplikasi terdapat fasilitas FAQ (Frequently Asked Question), konsumen nyaman mendapatkan pelayanan yang baik.
\end{abstract}

Kata kunci: Layanan Streaming Film Daring (Online), Bauran Pemasaran, Important Performance Analysis, Covid-19.

Abstract: Starting from the outbreak of a new type of Corona virus (SARS-CoV-2), which is called Corona Virus Disease 2019 (COVID-19), in the mainland of China to be precise in the

DOI: $10.52362 /$ jisamar.v5i2.438

Ciptaan disebarluaskan di bawah Lisensi Creative Commons Atribusi 4.0 Internasional. 
Journal of Information System, Applied, Management, Accounting and Research.

http://journal.stmikjayakarta.ac.id/index.php/jisamar , jisamar@stmikjayakarta.ac.id , jisamar2017@gmail.com

e-ISSN: 2598-8719 (Online), p-ISSN: 2598-8700 ( Printed), Vol. 5 No.2 Mei 2021

province of Wuhan at the end of 2019, all countries in the world seemed hit by a major crisis. The WFH scheme is part of the telecommuting concept (working remotely), which is actually not new in the world of work and urban planning, and has even been known since the 1970s as an effort to overcome traffic jams from commuting home to office every day. The government's policy to implement work from home (wfh) during the Covid-19 pandemic has made many people access other entertainment on the internet. One of them is by accessing streaming services. in the first quarter of 2020, there were 59 million installations for Viu. The marketing mix (7P) is the best step to consider all operational factors, this is because the marketing mix is seen in terms of products, (food and beverages), service, price and location. Over time, the marketing mix has developed into 7 factors, where the 3 additional factors are people, physical evidence and process. Important Performance Analysis is a technique used to measure the level of importance and level of performance of attributes. Assessment of the level of performance that can affect customer satisfaction will be represented by the letter $X$, while the assessment of the level of importance is represented by the letter $Y$. Based on the results of the research that has been done, it is concluded that the performance quality of the Viu application still does not meet the needs and desires of the customer. The unfulfilled needs and desires of customers are indicated by several attributes that fall into quadrant I on the Cartesian diagram, namely: selection or demand for films is served quickly, skills to attract consumers through online promos, complete and attractive collections, attract consumers through recommendations based on films that are preferred by consumers, on the site and application, there are FAQ (Frequently Asked Questions) facilities, consumers are comfortable getting good service.

Keywords: Streaming Online Film, Marketing Mix, Important Performance Analysis, Covid19

\section{PENDAhuluaN}

Bermula dari merebaknya virus Corona jenis baru (SARS-CoV-2), yang disebut Corona Virus Disease 2019 (COVID-19), di dataran negeri Tiongkok tepatnya di provinsi Wuhan pada akhir 2019, seluruh negara di dunia seolah dihantam krisis besar. Skema WFH merupakan bagian dari konsep telecommuting (bekerja jarak jauh), yang sebenarnya bukan hal baru dalam dunia kerja dan perencanaan kota, bahkan telah dikenal sejak tahun 1970-an sebagai salah satu upaya mengatasi kemacetan lalulintas dari perjalanan rumahkantor pulang-pergi setiap hari. Kebijakan pemerintah untuk menerapkan work from home (wfh) selama pandemi covid-19 berlangsung, membuat banyak orang mengakses hiburan lain di internet. Salah satunya dengan mengakses layanan streaming. pada kuartal I di 2020, tercatat sebanyak 59 juta pemasangan untuk Viu. Marketing mix (7P) merupakan langkah yang paling baik untuk mempertimbangkan segala factor operasional, hal ini dikarenakan marketing mix melihat dari segi produk, (makanan dan minuman), pelayanan, harga dan lokasi. Seiring perkembangan jaman, marketing mix berkembang menjadi 7 faktor dimana 3 faktor tambahannya itu berupa people, physical evidence serta process.

Pada penelitian ini penulis akan menggunakan metode Important Performance Analysis untuk mengukur tingkat kepentingan dan tingkat kinerja atribut. Penilaian tingkat kinerja yang dapat mempengaruhi kepuasan konsumen akan diwakili oleh huruf $\mathrm{X}$, sedangkan untuk penilaian tingkat kepentingan diwakili oleh huruf Y.

\section{TELAAH PUSTAKA}

DOI: $10.52362 /$ jisamar.v5i2.438

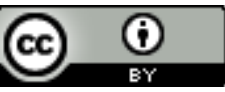

Ciptaan disebarluaskan di bawah Lisensi Creative Commons Atribusi 4.0 Internasional. 


\subsection{Perilaku Konsumen}

Istilah perilaku konsumen dartikan sebagai perilaku yang diperlihatkan oleh konsumen dalam mencari, membeli, menggunakan, mengefauas dan menghabiskan produk dan jasa yang mereka harapkan, dapat memuaskan kebutuhanya. Perilaku konsumen mengacu kepada perilaku pembelian individu pembelian terakhir dan rumah tangga yang membeli barang atau jasa untuk kosumsi pribadi. Jadi, dapat disimpulkan bahwa yang dimaksud dari perilaku konsumen merupakan suatu proses bagaimana konsumen dalam memilih, membeli, menggunakan, kemudian mengevaluasi, dan menghabiskan produk untuk memenuhi kebutuhan dan keinginannya.

\subsection{Bauran Pemasaran}

Untuk menciptakan nilai bagi pelanggan dan membangun hubungan pelanggan yang kuat dan menguntungkan, diperlukan strategi pemasaran yang handal. Strategi pemasaran adalah Logika pemasaran di mana perusahaan berharap untuk menciptakan nilai pelanggan dan mencapai hubungan yang menguntungkan. Perusahaan memutuskan pelanggan mana yang akan dilayaninya (segmentasi dan penetapan target) dan bagaimana cara perusahaan melayaninya (diferensiasi dan positioning). Perusahaan mengenali keseluruhan pasar, lalu membaginya menjadi segmen-segmen yang lebih kecil, memilih segmen yang paling menjanjikan, dan memusatkan perhatian pada pelayanan dan pemuasan pelanggan dalam segmen ini (Kotler dan Amstrong, 2008: 58).

\subsection{P's Strategi Pemasaran}

Dalam bauran pemasaran terdapat seperangkat alat pemasaran yang dikenal dalam istilah 4P, yaitu product (produk), price (harga), place (tempat atau saluran distribusi), dan promotion (promosi), sedangkan dalam pemasaran jasa memiliki beberapa alat pemasaran tambahan seperti people (orang), physical evidence (fasilitas fisik), dan process (proses), sehingga dikenal dengan istilah 7P mmaka dapat disimpulkan bauran pemasaran jasa yaitu product, price, place, promotion, people, process, physical evidence (Kotler dan Amstrong, 2012).

\subsection{Analisis Metode Importance Performance Analysus (IPA)}

Metode Importance Performance Analysis (IPA) pertama kali diperkenalkan oleh Martilla dan James (1977) dengan tujuan untuk mengukur hubungan antara persepsi konsumen dan prioritas peningkatan kualitas produk/jasa yang dikenal pula sebagai quadrant analysis (Brant dan Latu Everett (2000) dalam Amran dan Ponti Ekadeputra, 2010). IPA telah diterima secara umum dan dipergunakan pada berbagai bidang kajian karena kemudahan untuk diterapkan dan tampilan analisa yang memudahkan usulan perbaikan kinerja (Martinez, 2003). IPA mempunyai fungsi utama untuk menampilkan informasi berkaitan dengan faktor-faktor pelayanan yang menurut konsumen sangat mempengaruhi kepuasan dan loyalitas mereka, dan faktor-faktor pelayanan yang menurut konsumen perlu ditingkatkan karena kondisi saat ini belum memuaskan. Bagaimana tanggapan konsumen dapat dilihat dari penilaian yang diberikan oleh konsumen terhadap dimensi-dimensi bauran pemasaran yang terdapat dalam kuesioner. Hal ini ditujukan untuk mengukur atribut-atribut atau dimensi dari tingkat kepentingan dan tingkat pelaksanaan yang diharapkan konsumen dan sangat berguna dalam pengembangan program strategi pemasaran yang efektif digunakan metode Important Performance Analysis (Simamora, 2004).

Important Performance Analysis merupakan suatu teknik yang digunakan untuk mengukur tingkat kepentingan dan tingkat kinerja atribut. Penilaian tingkat kinerja yang dapat mempengaruhi kepuasan konsumen akan diwakili oleh huruf $\mathrm{X}$, sedangkan untuk penilaian tingkat kepentingan diwakili oleh huruf Y. Untuk menilai kinerja dan kepentingan kosumen digunakan skor seperti terlihat pada Tabel 2.1.

Tabel 2. 1 Skor Penilaian Kinerja dan Tingkat Kepentingan Konsumen

\begin{tabular}{|c|c|c|}
\hline Skor & Kineria & Kepentingan \\
\hline Skor 1 & Sangat Tidak Baik & Sangat Tidak Penting \\
\hline Skor 2 & Tidak Baik & Tidak Penting \\
\hline Skor 3 & Baik & Penting \\
\hline Skor 4 & Sangat Baik & Sangat Penting \\
\hline
\end{tabular}

DOI: $10.52362 /$ jisamar.v5i2.438

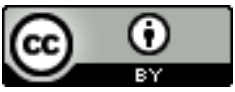

Ciptaan disebarluaskan di bawah Lisensi Creative Commons Atribusi 4.0 Internasional. 
Total penilaian tingkat kinerja dan kepentingan diperoleh dengan cara menjumlahkan skor penilaian yang diberikan konsumen. Hasil perhitungan akan digambarkan dalam diagram kartisius. Masing-masing atribut diposisikan dalam diagram tersebut berdasarkan skor rata-rata, dimana skor rata-rata penilaian kinerja (X) menunjukkan posisi suatu atribut pada sumbu X, sedangkan posisi atribut pada sumbu Y ditunjukkan oleh skor rata-rata tingkat kepentingan $(\mathrm{Y})$. Adapun rumus yang digunakan adalah:

$$
X=\frac{\mathrm{n}_{i=1} Y^{i}}{\mathrm{n}} \quad Y=\frac{\mathrm{n}_{i-1} X^{i}}{\mathrm{n}}
$$

Keterangan:

$\mathrm{X}=$ Skor rata-rata

$\mathrm{Y}=$ Skor rata-rata tingkat kepentingan

$\mathrm{N}=$ Jumlah data konsumen

Diagram kartesius merupakan ruang yang dibagi atas empat bagian dan dibatasi oleh dua buah garis yang berpotongan tegak lurus pada titik-titik $(a, b)$. Titik tersebut diperoleh dari rumus Yi.

$$
a=\frac{X i}{k} \quad b=\frac{Y i}{k}
$$

Keterangan :

$\mathrm{a}=$ Batas sumbu $\mathrm{X}$ (tingkat kinerja)

$\mathrm{b}=$ Batas sumbu Y (tingkat kepentingan)

$\mathrm{k}=$ Banyaknya atribut yang diteliti 2.1 .

Selanjutnya setiap atribut tersebut dijabarkan dalam diagram kartesius seperti yang terlihat pada Gambar

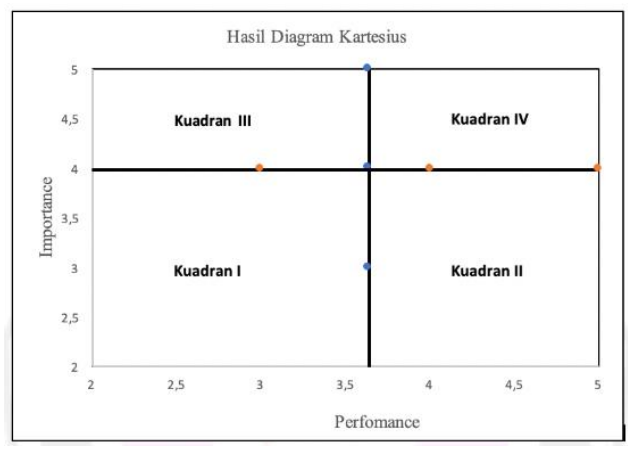

Gambar 2.1 Diagram Kartesius

2.5 Covid-19

CoronaVirus-19 Coronavirus merupakan virus RNA strain tunggal positif, berkapsul dan tidak bersegmen. Coronavirus tergolong ordo Nidovirales, keluarga Coronaviridae. Coronavirus dibagi menjadi dua subkeluarga

DOI: $10.52362 /$ jisamar.v5i2.438

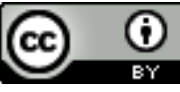

Ciptaan disebarluaskan di bawah Lisensi Creative Commons Atribusi 4.0 Internasional. 
dibedakan berdasarkan serotype dan karakteristik genom. Terdapat empat genus yaitu alpha coronavirus, betacoronavirus, deltacoronavirus dan gamma coronavirus. CoronaVirus adalah keluarga besar virus yang menyebabkan penyakit mulai dari gelaja ringan sampai berat. Ada setidaknya dua jenis coronavirus yang diketahui menyebabkan penyakit yang dapat menimbulkan gejala berat seperti Middle East Respiratory Syndrome (MERS) dan Severe Acute Respiratory Syndrome (SARS). Coronavirus Disease (COVID-19) adalah virus jenis baru yang belum pernah diidentifikasi sebelumnya pada manusia.

\section{METODE PENELITIAN}

\subsection{Objek Penelitian}

Adapun objek penelitian yang dilakukan untuk melihat perilaku konsumen pada layanan streaming film daring (online) di Indonesia dengan Bauran Pemasaran (Marketing Mix) yaitu Produk, Harga, Tempat dan Promosi, People, Physical Evidence, Process.

3.2 Metode Penelitian

Langkah-langkah yang akan dilakukan dalam melakukan penelitian ini dapat dilihat pada gambar berikut.

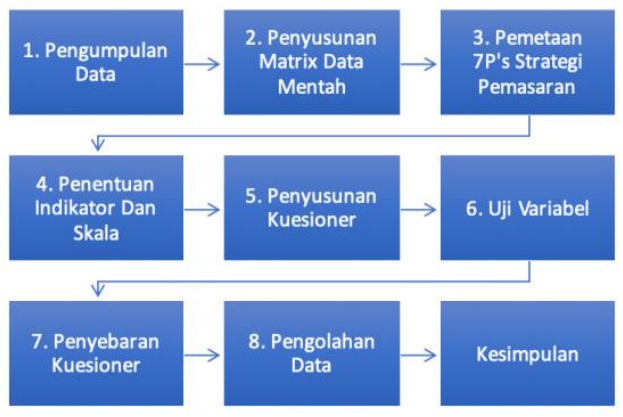

Gambar Tahapan Penelitian

\section{HASIL PENELITIAN DAN PEMBAHASAN}

4.1 Deskripsi Responden

Responden dalam penelitian ini adalah pengguna Viu. Peneliti memberikan daftar kuesioner atau daftar pertanyaan yang hasilnya ditabulasikan dan kemudaian dianalisis.

1. Identifikasi Responden Berdasarkan Jenis Kelamin.

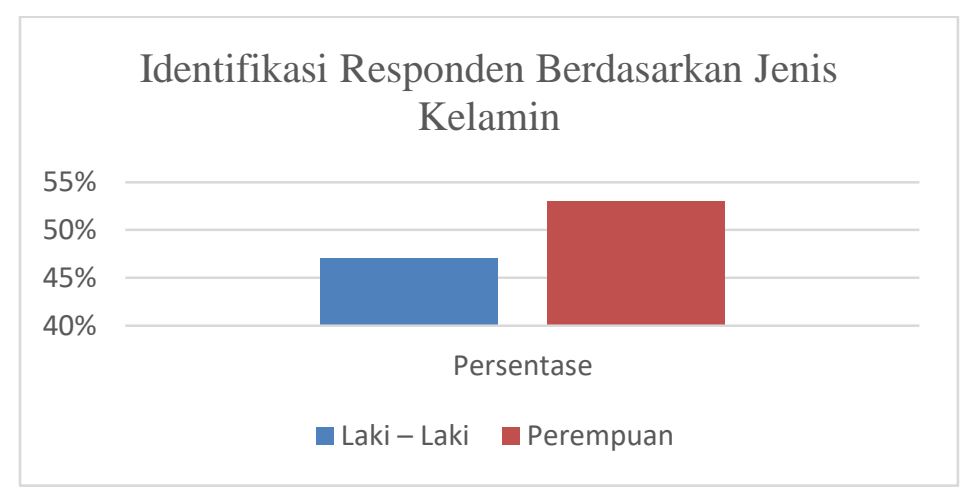

DOI: $10.52362 /$ jisamar.v5i2.438

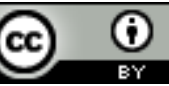

Ciptaan disebarluaskan di bawah Lisensi Creative Commons Atribusi 4.0 Internasional. 
Gambar Identifikasi Responden Berdasarkan Jenis Kelamin

Berdasarkan hasil penelitian dari 100 orang responden, diketahui bahwa sebesar 53\% responden adalah berjenis kelamin laki - laki, dan sisanya $47 \%$ responden berjenis kelamin perempuan.

2. Identifikasi Responden Berdasarkan Usia

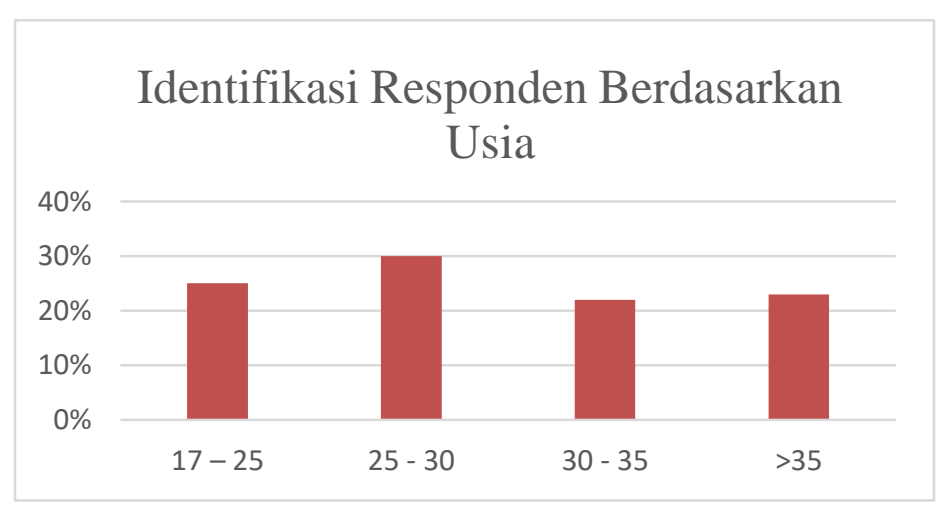

Gambar Identifikasi Responden Berdasarkan Usia

Berdasarkan hasil penelitian dari 100 orang responden, diketahui bahwa jumlah tertinggi yaitu pada usia 25-30 tahun dengan persentase sebesar $30 \%$.

3. Identifikasi Responden Berdasarkan Tingkat Pendidikan

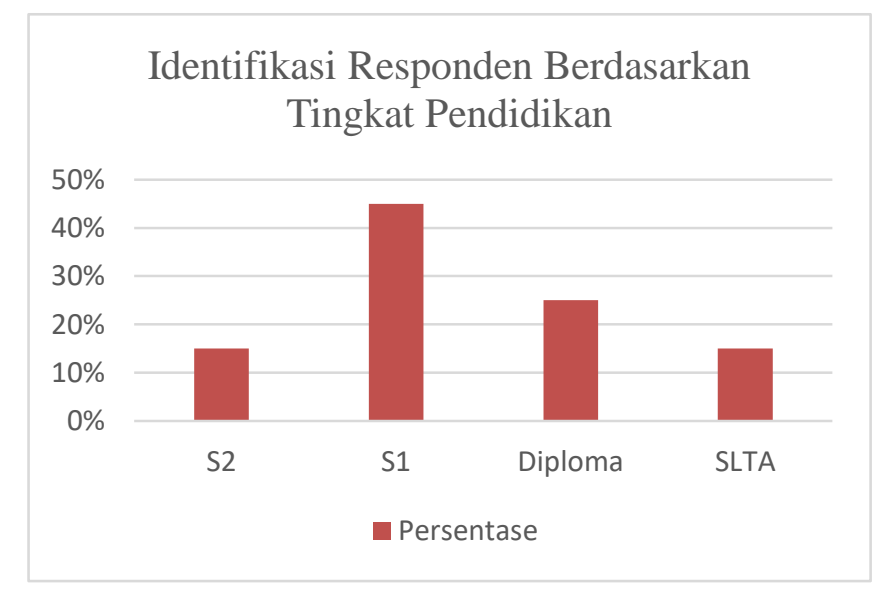

Gambar Identifikasi Responden Berdasarkan Pendidikan

Berdasarkan hasil penelitian terhadap 100 responden, diketahui sebesar 15\% responden adalah S2. Sedangkan $45 \%$ adalah S1. Sedangkan 25\% adalah Diploma dan siasanya 15\% adalah SLTA.

4. Identifikasi Responden Berdasarkan Tingkat Frekuensi Menonton Film Daring (Online). 


\section{Identifikasi Responden Berdasarkan \\ Frekuensi Menonton Film Daring \\ (Online)}

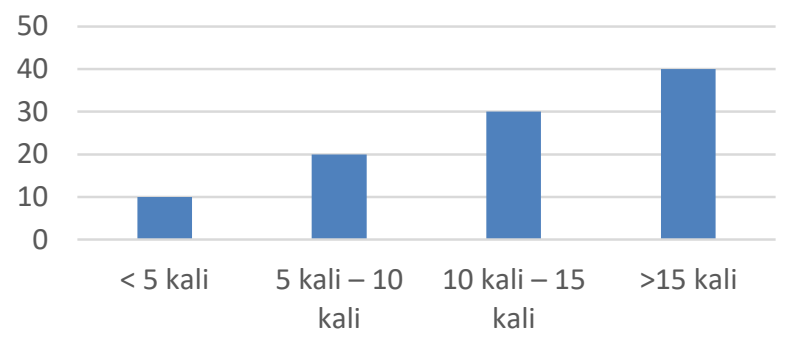

Gambar Identifikasi Responden Berdasarkan Frekuensi Menonton Film Daring (Online)

Berdasarkan hasil penelitian terhadap 100 responden, diketahui bahwa frekuensi menonton film daring (online) dalam sebulan sebesar $10 \%$ dalam kurun waktu $<5$ kali dalam sebulan, sebesar $20 \%$ dalam kurun waktu 5 kali - 10 kali dalam sebulan, sebesar 30\% dalam kurun waktu 10 kali - 15 kali dalam sebulan dan sebesar 40\% dalam kurun waktu > 15 kali dalam sebulan.

\subsection{Uji Validitas}

Uji validitas digunakan untuk menguji sejauh mana ketepatan alat pengukur dapat mengungkapkan konsep gejala/kejadian yang diukur. Uji validitas digunakan untuk mengukur sah atau tidaknya suatu kuesioner, suatu kuesioner dikatakan valid jika pertanyaan pada kuesioner mampu untuk mengungkapkan sesuatu yang akan diukur oleh kuesioner tersebut.

Uji validitas dihitung dengan membandingkan nilai $r$ hitung (Correlated Item - Total Correlation) dengan nilai $\mathrm{r}$ tabel, jika $\mathrm{r}$ hitung > dari $\mathrm{r}$ tabel (pada taraf signifikansi 5\%) maka pertanyaan tersebut dinyatakan valid. Dalam penelitian ini sampel (n) yang digunakan sebanyak 100 responden, maka besarnya df dapat dihitung $100-2=98$. Dengan $\mathrm{df}=98$ dan alpha $=0.05$ sehingga di dapat $\mathrm{r}$ table $=$ 0.197 (dengan melihat $r$ tabel dengan uji dua sisi). Hasil pengujian diperoleh sebagai berikut :

\section{Tabel 4. 1 Hasil Uji Validitas}

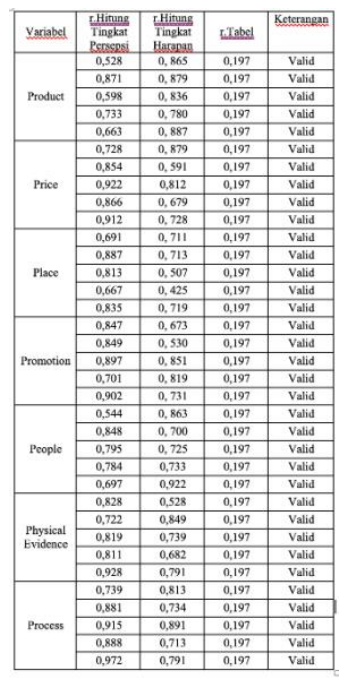

DOI: $10.52362 /$ jisamar.v5i2.438

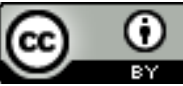

Ciptaan disebarluaskan di bawah Lisensi Creative Commons Atribusi 4.0 Internasional. 


\section{Sumber : Perhitungan dengan menggunakan SPSS versi 25}

Dari tabel 4.12 diperoleh hasil bahwa semua nilai $r$ hitung $>0,197$ sehinnga dapat disimpulkan bahwa semua pernyataan dapat dinyatakan valid.

\subsection{Hasil Importance Performance Analysis (IPA)}

Metode IPA digunakan untuk mengukur sejauh mana kinerja dari kualitas Aplikasi Viu dalam memenuhi harapan konsumen, sehingga konsumen merasa puas. Tahapan metode IPA terdiri atas analisis persepsi dan harapan, serta analisis kesesuaian.

Nilai total dari keseluruhan penilaian pada tiap atribut diperoleh dari setiap konsumen. Total penilaian tingkat persepsi $(X i)$ dan penilaian tingkat harapan $(Y i)$ dirata-ratakan terhadap jumlah konsumen yang terlibat dalam penelitian ini yaitu sebanyak 100 orang sehingga diperoleh nilai rata-rata tingkat persepsi dan harapan tiap atribut. Nilai rata-rata terhadap penilaian tingkat persepsi $(X)$ menunjukkan posisi suatu atribut pada sumbu $\mathrm{X}$ dan nilai rata-rata terhadap penilaian tingkat harapan $(Y)$ menunjukkan posisi atribut terhadap sumbu $\mathrm{Y}$. Masing-masing nilai rata-rata tingkat persepsi dan harapan atribut selanjutnya di plot kedalam diagram kartesius untuk melihat posisi atribut tersebut dalam kuadaran tertentu.

\subsection{Hasil Analisa Diagram Kartesius}

Analisa Diagram Kartesius Analisis diagram kartesius masing-masing atribut pada tingkat harapan dan tingkat persepsi dapat digunakan untuk mengetahui secara rinci atribut-atribut yang paling penting dan untuk menyusun peringkat berbagai atribut pada ketujuh dimensi yaitu produk, harga, tempat, promosi, orang, proses dan bukti fisik kedalam sebuah diagram kartesius, sehingga dapat diperoleh gambaran faktor-faktor atribut yang menjadi prioritas untuk dilakukan perbaikan agar diperoleh kepuasan pelanggan. Berdasarkan hasil perhitungan nilai rataan tingkat persepsi dan harapan maka skor rataan untuk tingkat persepsi sebesar 3,639dan tingkat harapan sebesar 3,982. Menurut Supranto (2006), penilaian rata-rata untuk tingkat kepentingan dan tingkat kinerja digunakan sebagai pembagi diagram Importance-Performance Analysis menjadi empat bagian. Atribut yang memiliki total bobot melebihi skor rataan berarti memiliki tingkat persepsi dan harapan yang tinggi. Untuk lebih jelasnya, nilai rataan tingkat persepsi dan harapan dapat dilihat pada Tabel 4.31.

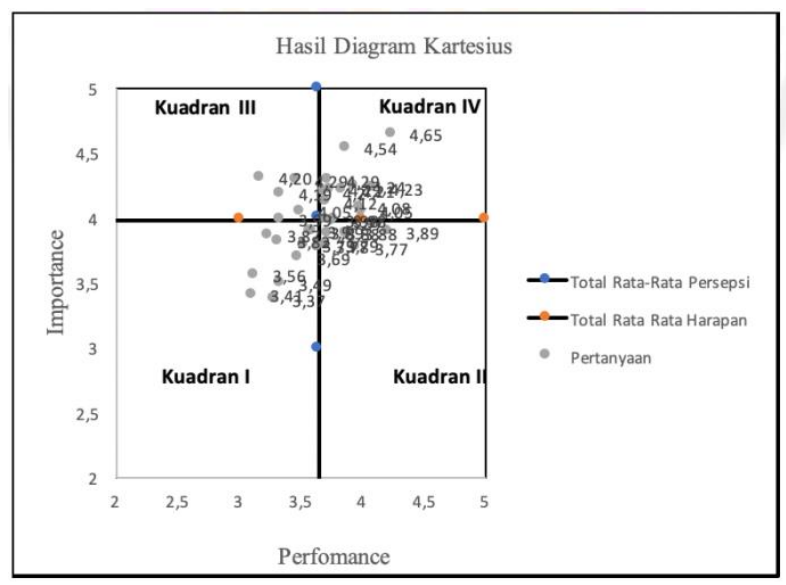

Gambar 4. 1 Hasil Diagram Kartesius 
Tabel 4. 2 Keterangan Hasil Diagram Kartesius
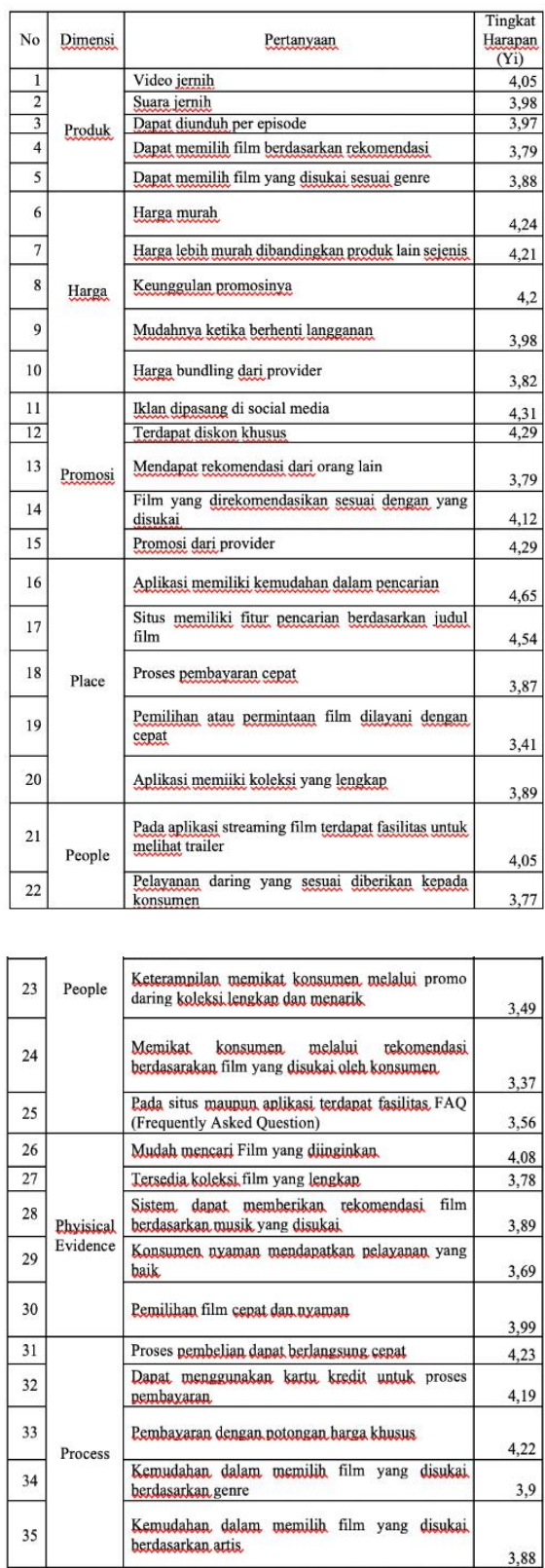

Sumber : Hasil Pengolahan Data Primer

\section{KESIMPULAN}

5.1 Kesimpulan

Berdasarkan hasil penelitian yang telah dilakukan, diperoleh kesimpulan bahwa kualitas kinerja aplikasi Viu masih belum memenuhi kebutuhan dan keinginan pelanggan. Tidak terpenuhinya kebutuhan dan keinginan pelanggan ditunjukkan oleh beberapa atribut yang masuk kedalam kuadran I pada diagram kartesius, yaitu: pemilihan atau permintaan film dilayani dengan cepat, keterampilan memikat konsumen melalui promo daring koleksi lengkap dan menarik, memikat konsumen melalui rekomendasi berdasarakan film yang disukai oleh

DOI: $10.52362 /$ jisamar.v5i2.438

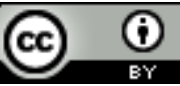

Ciptaan disebarluaskan di bawah Lisensi Creative Commons Atribusi 4.0 Internasional. 
konsumen, pada situs maupun aplikasi terdapat fasilitas FAQ (Frequently Asked Question), konsumen nyaman mendapatkan pelayanan yang baik.

5.2 Saran

1. Berdasarkan hasil penelitian diharapkan pihak Viu dapat memperbaiki atribut atribut yang masuk kedalam kuadran I sebagai prioritas utama untuk dilakukan perbaikan sesuai dengan urutan prioritasnya.

2. Pada penelitian lebih lanjut, diharapkan diperbanyak kembali untuk jumlah respondennya, dikarenakan untuk melihat sejauh mana aplikasi Viu digunakan secara luas.

\section{REFERENASI}

[1] Muharastri, Y. 2008. Analisis Kepuasan Konsumen Susu UHT Merek Real Good Di Kota Bogor. Jurusan Teknologi Industri Pertanian. 100 Teknologi Pertanian. Institut Pertanian Bogor. Bogor. Hal 12.

[2] Simamora, B. 2004. Riset Pemasaran. PT. Gramedia Pustaka Utama. Jakarta. Hal 197.

[3] Santoso. 2011. Persepsi Konsumen Terhadap Kualitas Bakpao Telo Dengan Metode Importance Performance Analysis (IPA). Jurnal Teknologi Pertanian 12(1) : 9.

[4] Maiyanti, S.I. 2009. Aplied Customer Satisfaction Index (CSI) and Importance- Performance Analysis (IPA) to know Student Satisfaction Level of Sriwijaya University Library Services. Jurusan Matematika. Fakultas MIPA. Universitas Sriwijaya. Jakarta. Hal 08.

[5] Harjanto, R.N. 2010. Analisis Pengaruh Harga, Produk, Kebersihan, Dan Kualitas Layanan Terhadap Kepuasan Pelanggan (Studi Kasus Pada Restoran Mamamia Cabang Mrican Semarang). Jurusan manajemen. Fakultas ekonomi. Universitas diponegoro. Semarang. Hal 06.

[6] Lukman, H.N 2014. Analsis Kepuasan Pelanggan Hikmah Catering Dalam Meningkatkan Kualitas Layanan Dengan Metode Importacne Performace Analysis (Pada Studi Kasus SDIT Al-Hikmah). Jurusan Teknologi Industri. Fakultas Teknologi Industri . Universitas Gunadarma. Depok.Hal 37.

[7] Lulu, DA 2014. ANALISIS PERSEPSI KONSUMEN MENGGUNAKAN METODE IMPORTANCE PERFORMANCE ANALYSIS DAN CUSTOMER SATISFACTION INDEX (Studi Kasus di Ria Djenaka Coffee \& Resto, Malang). Jurusan Teknologi Industri Pertanian. Fakultas Teknologi Pertanian. Universitas Brawijaya. Malang. Hal 7.

[8] Web Portal Kementerian Keuangan Republik Indonesia 05 Mei 2020. COVID-19, Work From Home, dan Revolusi Industri 4.0. Available at : https://www.djkn.kemenkeu.go.id/kpknl-parepare/bacaartikel/13058/COVID-19-Work-From-Home-dan-Revolusi-Industri-40.html

[9] Rizki, A 2019. Analisis Perilaku Konsumen Pada Pembelian Daring (Online) Di Indonesia Dengan Mengimplementasikan 7P'S Strategi Pemasaran Menggunakan Quality Fuction Development (QFD). Jurusan Magister Manajemen Sistem Informasi. Fakultas Sistem Informasi. Universitas Gunadarma. Hal 40 . 


\section{SURAT PERNYATAAN KEASLIAN NASKAH (Statement of Authenticity of Status)}

Yang bertanda tangan di bawah ini menyatakan bahwa:

Judul naskah: ANALISIS PERSEPSI KONSUMEN PENGGUNA

LAYANAN STREAMING FILM DARING (ONLINE) PADA MASA PANDEMI COVID19 MENGGUNAKAN METODE IMPORTANCE PERFORMANCE ANALYSIS (IPA)

Penulis:

1. Nama : Muhamad Zaini

e-mail : muhamadzaini542@gmail.com

2. Nama : Maukar

e-mail :

Nama dan alamat penulis 1 (perwakilan) untuk korespondensi:

Nama : Muhamad Zaini

Alamat: Universitas Gunadarma, 1. Margonda Raya No.345c, Depok, Kecamatan Beji, Kota Depok, Jawa Barat 16424

Telp. : 62 877-8429-7030

e-mail : muhamadzaini542@gmail.com

- Jurnal/Artikel tersebut di atas merupakan naskah asli, hasil karya penulis, dan bukan merupakan plagiat dari artikel atau karya ilmiah orang lain.

- Jurnal/Artikel tersebut di atas belum pernah dipublikasikan atau tidak sedang diajukan untuk dimuat pada jurnal atau media lainnya.

- Apabila kemudian hari pernyataan ini tidak benar, maka penulis bersedia menerima sanksi dengan peraturan perundang-undangan yang berlaku.

Penulis 1,

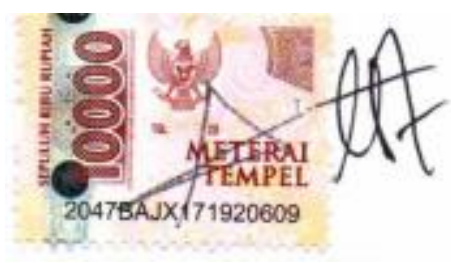

(MUHAMAD ZAINI)
Penulis 2,

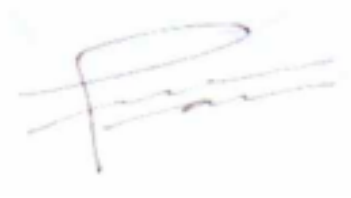

(MAUKAR)

Note : * Hapus yang tidak perlu (disesuaikan) 


\section{SURAT PERNYATAAN KESEDIAAN PUBLIKASI \\ (Statement of Publication Availability)}

Saya yang bertandatangan di bawahini :

Nama (Penulis 1) : Muhamad Zaini

Asal Institusi : Universitas Gunadarma

No.Telepon : : 087784297030

Email_:muhamadzaini542@gmail.com

Bersama ini saya menyatakan BERSEDIA untuk publikasi paper dengan judul :

ANALISIS PERSEPSI KONSUMEN PENGGUNA LAYANAN STREAMING FILM

DARING (ONLINE) PADA MASA PANDEMI COVID-19 MENGGUNAKAN METODE

IMPORTANCE PERFORMANCE ANALYSIS (IPA)

Di JISAMAR (Journal of Information System, Applied, Management, Accounting and Research) :

Vol 5 No 2 Tahun 2021

Saya menyatakan bahwa karya ilmiah tersebut di atas terbebas dari unsure plagiarism dan publikasi ganda (belum pernah dipublikasikan ke media manapun).Serta tidak akan diterbitkan ulang padaJ urnal/Buku dan atau majalah lainnya.

Saya juga bersedia membayar biaya publikasi pada JISAMAR (Journal of Information System, Applied, Management, Accounting and Research) sesuai ketentuan dan aturan yang berlaku**).

Demikian surat pernyataan ini dibuat dalam keadaan sehatwal'afiat tanpa paksaan dari pihak manapun dan agar dapat dipergunakan sebagaimana mestinya.

Jakarta, 28, April, 2021

Yang MembuatPernyataan

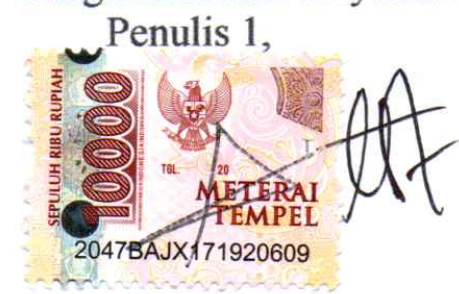

( MUHAMAD ZAINI )

Penulis 2

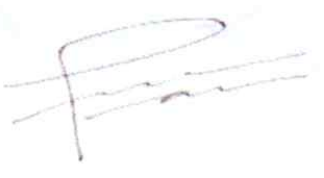

( MAUKAR )

Note :

* :Coret yang tidak sesuai(disesuaikan)

** :Dibayar setelah artikel dinyatakan SIAP PUBLISH. Biaya publikasi bisa dilihat di web JISAMAR 